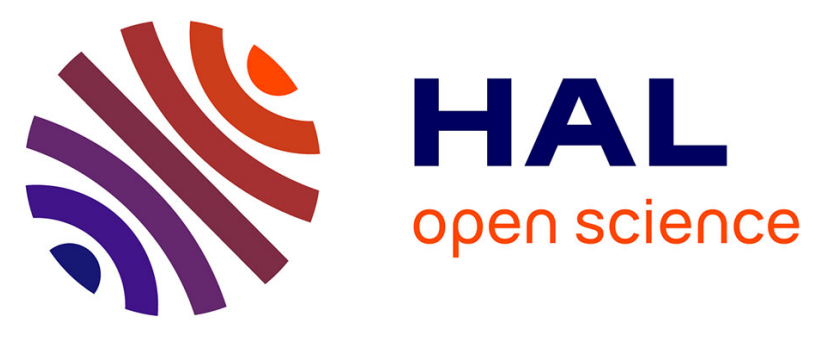

\title{
Cost-effectiveness threshold of first-trimester Down syndrome maternal serum screening for the use of cell-free DNA as a second-tier screening test
}

Marie Blanquet, Sophie Dreux, Stéphanie Léger, Corinne Sault, Charline Mourgues, Hélène Laurichesse, Didier Lémery, Françoise Vendittelli, Anne Debost-Legrand, Françoise Muller

\section{To cite this version:}

Marie Blanquet, Sophie Dreux, Stéphanie Léger, Corinne Sault, Charline Mourgues, et al.. Costeffectiveness threshold of first-trimester Down syndrome maternal serum screening for the use of cell-free DNA as a second-tier screening test. Annales de Biologie Clinique, 2021, 79 (4), pp.331-338. 10.1684/abc.2021.1656 . hal-03439596

\section{HAL Id: hal-03439596 https://hal.uca.fr/hal-03439596}

Submitted on 22 Nov 2021

HAL is a multi-disciplinary open access archive for the deposit and dissemination of scientific research documents, whether they are published or not. The documents may come from teaching and research institutions in France or abroad, or from public or private research centers.
L'archive ouverte pluridisciplinaire HAL, est destinée au dépôt et à la diffusion de documents scientifiques de niveau recherche, publiés ou non, émanant des établissements d'enseignement et de recherche français ou étrangers, des laboratoires publics ou privés. 
1 Titre : Evaluation de la valeur seuil la plus cout-efficace des marqueurs sériques du 1er trimestre pour l'emploi du test d'ADN circulant dans le dépistage de la trisomie 21 : une analyse médico-économique.

Titre court : Analyse cout-efficacité de la stratégie de dépistage de la trisomie 21

Title: Cost-effectiveness threshold of first-trimester Down syndrome maternal serum screening for the use of cell-free DNA as a second-tier screening test

Short-title: Cost-effectiveness study of Down syndrome screening strategy

Institute where the work was conducted: CHU of Clermont-Ferrand. France

Marie Blanquet ${ }^{1,2}$, Sophie Dreux ${ }^{3}$, Stéphanie Léger ${ }^{4}$, Corinne Sault ${ }^{5}$, Charline Mourgues ${ }^{2,6}$, Hélène Laurichesse ${ }^{2,7}$, Didier Lémery ${ }^{2,7}$, Françoise Vendittelli ${ }^{2,7}$, Anne Debost-Legrand ${ }^{2,7}$, Françoise Muller ${ }^{3}$.

${ }^{1}$ Service de Médecine, Centre Hospitalier de Mauriac, Mauriac, France

${ }^{2}$ Université Clermont Auvergne, CNRS-UMR 6602, Institut Pascal, Axe TGI, Péprade, Clermont-Ferrand, France

${ }^{3}$ Laboratoire de Biochimie-Hormonologie, Hôpital Robert Debré, APHP, Paris, France

${ }^{4}$ Laboratoire de mathématiques UMR CNRS 6620, Université Blaise Pascal; CNRS, UMR 6620, Laboratoire de mathématiques, Aubière, France.

${ }^{5}$ Laboratoire Eurofins Biomnis, Lyon, France.

${ }^{6}$ Direction de la Recherche Clinique, Centre Hospitalier Universitaire de Clermont-Ferrand, Clermont-Ferrand, France

${ }^{7}$ Pôle Femme et Enfant, Centre Hospitalier Universitaire de Clermont-Ferrand, ClermontFerrand, France 


\section{Corresponding author}

3 Dr Anne Debost-Legrand

4 CHU de Clermont-Ferrand, Pôle Femme et Enfant, place Lucie et Raymond Aubrac, 63003

5 Clermont-Ferrand

6 Phone number: 0033 473750715/Fax: 0033(0)473750619

7 Email address: $\underline{\text { alegrand @ chu-clermontferrand.fr }}$

8

9 Mots-clefs: test ADN libre circulant, Trisomie 21, dépistage prénatal, analyse économique, 10 ratio cout-efficacité,

11 Keywords: Non-invasive prenatal testing, Down syndrome, prenatal screening, economic 12 analysis, cost-effectiveness ratio. 


\section{Résumé}

2 Introduction: Notre objectif était d'identifier la valeur seuil la plus cout-efficace des 3 marqueurs sériques du $1^{\text {er }}$ trimestre pour l'intégration du test $\mathrm{ADN}$ libre circulant en

4 deuxième ligne dans le cadre du dépistage prénatal de la trisomie 21 en France.

5 Matériel et méthodes: Une analyse cout-efficacité a été menée sur 108121 grossesses 6 uniques en utilisant un modèle de simulation. Les valeurs seuils testées des marqueurs 7 sériques du $1^{\mathrm{er}}$ trimestre étaient comprises entre $1 / 51$ et $1 / 1000$ par pas de $1 / 50$. La valeur seuil la plus coût-efficace a été déterminée par le calcul du ratio coût-efficacité (RCE, coûts= coûts directs médicaux après le dosage des marqueurs du $1^{\text {er }}$ trimestre, efficacité=nombre de cas de trisomie 21 dépisté).

Résultat: Dans notre échantillon, 161 cas de trisomie 21 ont été identifiés. Pour une valeur seuil $\geq 1 / 50,47,2 \%$ des cas ont été diagnostiqués. Dans le modèle de simulation, pour un seuil $\geq 1 / 250,73,9 \%$ des cas de trisomie 21 étaient identifiés, pour un seuil $\geq 1 / 500$, le pourcentage de détection s'élevait à $78,8 \%$ et pour un seuil $\geq 1 / 1000,2$ cas supplémentaires ont été identifiés. Le montant des coûts était stable pour un seuil $\geq 1 / 250$ (978 634€), puis augmentait rapidement pour un seuil $\geq 1 / 500$ (1 966 576€) et devenait exponentiel pour un seuil $\geq 1 / 1000$ (3 $980216 €$ ). Le RCE pour le seuil $\geq 1 / 500$ était de 38560 .

Conclusion : La valeur seuil la plus coût-efficace pour l'implémentation du test ADN libre circulant en deuxième ligne semble être $\geq 1 / 500$. 


\section{Abstract}

2 Introduction: We aimed to identify the most relevant cost-effectiveness threshold of first-

3 trimester Down syndrome (DS) maternal serum screening (T21T1) for the use of cell-free

4 DNA (cfDNA) as a second-tier test in the French context.

5 Method: A cost-effectiveness analysis was performed on 108121 singleton pregnancies

6 using a simulation model. The threshold of T21T1 screening was ranged from 1/51 to 1/1000

7 in steps of 1/50. The most relevant threshold was based on cost-effectiveness ratio (CER;

8 costs $=$ direct medical costs after T21T1 screening/ effectiveness $=$ number of DS cases

9 identified).

Results: In the sample, 161 cases of DS were identified. At the threshold of $\geq 1 / 50,47.2 \%$ of total DS cases were diagnosed. In the simulation model, for a threshold $\geq 1 / 250,73.9 \%$ of total DS cases were diagnosed, for $\geq 1 / 500,78.8 \%$ and for $\geq 1 / 1000$, only two additional cases were diagnosed. The slope of the cost increase was slight from threshold $\geq 1 / 250$ (978 $634 €$ ), then steep up to $1 / 500$ (1 $966576 €$ ) and increased exponentially to $1 / 1000$ (3 980 $216 €)$. The CER was 38560 for a threshold $\geq 1 / 500$.

Conclusion: The most cost-effective threshold for cfDNA as a second-tier test seems to be $\geq$ 1/500. For higher thresholds, costs increase dramatically for only a few additional cases of DS identified. 


\section{Introduction}

Over the last 50 years, prenatal diagnosis procedures and screening have become safer and the capabilities of diagnostic laboratories have expanded[1-6]. Recently, the use of cellfree DNA (cfDNA) has dramatically increased. While cfDNA is considered as a screening test and not a diagnostic test by the scientific community, patients and most physicians see cfDNA as a substitute for foetal karyotyping[7-9].

Recently, new guidelines drawn up by the French National Authority for Health (HAS; Haute Autorité de Santé) recommend cfDNA for Down syndrome (DS) screening[10]. These guidelines, based on a cost-effectiveness analysis, recommend cfDNA as a second-tier screening test in women with a risk between 1/51 and 1/1000 after first-trimester combined maternal serum screening (T21T1). Moreover, in high-risk women (T21T1 $\geq 1 / 50)$, invasive testing is proposed but, after clear information, women still have the choice of cfDNA. However, these guidelines were based on simulated data.

CfDNA is a reliable technique that should be included in DS screening, but it remains contingent on maternal serum screening and the terms of application need to be carefully defined. It is necessary to identify the most relevant threshold of the calculated risk of DS based on maternal serum markers for the use of cfDNA. Few studies have tested different thresholds of T21T1 to identify the most cost-effective one[11-14]. Even though these studies reached similar conclusions, the number of thresholds tested was limited and there was no step-by-step analysis. The principal objective of this study was to identify the most relevant cost-effectiveness threshold of T21T1 screening for use of cfDNA as a second-tier test, by carrying out an economic analysis, in the French context.

\section{Methods}

French prenatal screening for Down syndrome 
In France, prenatal DS screening has been regulated by the Ministry of Health since 1997[15]. The French DS screening policy is organized at a national scale and since 2010 has been based on three steps. The first consists of first-trimester nuchal translucency (NT) and crown rump length (CRL) measurements (T1US), a cut-off $\geq 3.5 \mathrm{~mm}$ leading to chorionic villus sampling (CVS) for karyotyping. The second step consists of first-trimester maternal serum screening (or second-trimester when NT is not performed or when maternal blood sampling is performed after $13^{+6}$ weeks of gestation). First-trimester DS maternal serum screening (T21T1) is performed at $11-13^{+6}$ weeks and combined maternal age, maternal serum markers (pregnancy-associated plasma protein A, PAPP-A, and free beta-human chorionic gonadotropin, hCG $\beta$ ) and nuchal translucency (NT). Karyotyping is offered for a calculated risk $\geq 1 / 50$. If women have a risk between $1 / 51$ and $1 / 1000$ after first-trimester combined maternal serum screening (T21T1), cfDNA is recommended as a second-tier screening test[10]. The third step consists of two ultrasound scan examinations at 20-22 weeks and 3032 weeks of gestation.

\section{Study population}

Our economic analysis was applied to data from 108121 singleton pregnancies with T21T1 (Autodelfia, dual kit and LifeCycle 4.1 software, PerkinElmer, Turku, Finland) during the year 2015 in the Biomnis Eurofins Laboratory, one of 86 accredited laboratories. Maternal serum markers and NT were expressed as multiple of the median (MoM) for gestational age (expressed in weeks and days of amenorrhea) as estimated by CRL measurement performed at the same time as NT. MoMs were adjusted for three confounding factors (maternal weight, smoking status and ethnicity). In accordance with French law, written informed consent for biochemical testing was obtained from each woman. 
If chorionic villous sampling or amniocentesis was performed, a second written consent was needed for foetal karyotyping. The database has been reported to the French Data Protection Authority (CNIL: Commission Nationale de l'Informatique et des Libertés) as CNIL no. 1839545 V1.

\section{Economic analysis}

\section{Identification of DS in the database}

Cases in which embryo reduction was performed and cases in which a vanishing twin was detected at ultrasound scan were excluded. Because of the French policy using NT as contingent screening, all cases with $\mathrm{NT} \geq 3.5 \mathrm{~mm}$ were excluded from the analysis. DS cases were identified prenatally when women had T21T1 screening $\geq 1 / 250$ (based on French policy of DS screening strategy in 2015) or when anomalies were detected at ultrasound scan or at birth when the patient did not opt for an invasive procedure or for termination of pregnancy or when T21T1 was $<1 / 250$ or without ultrasound anomalies. To sum up, among 108121 singleton pregnancies 161 cases of DS were diagnosed, 124 by T21T1 screening, 16 by means of abnormal ultrasound scans and 21 at birth. All karyotyping results for the cohort were collected by the accredited laboratory, which performed serum marker screening.

\section{Simulation model}

The simulation model was based on actual data regarding DS status (including overall cases) and T21T1 results. Three variables were simulated based on assumptions from the international literature or expertise. Those variables were the women's characteristics (body weight and ethnicity), cfDNA (sensitivity, specificity and failure rate) and karyotyping acceptance rate. Women whose $\mathrm{T} 21 \mathrm{~T} 1$ results indicated a risk $\geq 1 / 1000$ were considered to be part of a high-risk group in the simulation model, so the acceptability of cfDNA testing and karyotyping was presumed to be high. Table 1 presents the percentages with the $95 \%$ confidence intervals of each variable included in the model. 
Cost-effectiveness analysis

A cost-effectiveness analysis (CEA) was performed for different thresholds and calculated risk as a discrete variable of T21T1 screening was used to identify the most relevant threshold. Figure 1 depicted the decision tree model used in the analysis describing the clinical pathway where cfDNA was used as a second-tier test if T21T1 screening was positive starting from $\geq 1 / 50$ to $\geq 1 / 1000$ by step of $1 / 50$.

The perspective chosen was that of the third-party payer, ie, the French national health insurance fund (Caisse Nationale d'Assurance Maladie). Expressed in euros, the costs included were the direct medical costs after T21T1 screening: the cost of karyotyping, the invasive technique and the procedure used (chorionic villus sampling or amniocentesis) and of karyotype analysis (Table 1). Costs were calculated for the sample of 108121 women. The incremental cost per DS case diagnosed was also calculated. The medical and societal costs of an undetected DS-affected child were not taken into account. The costs and effectiveness criteria were based on data from a single year and have not been actualized[16,17].

The most relevant threshold of T21T1 screening for use of cfDNA as a second-tier test was based on cost-effectiveness ratio (CER). The criterion of effectiveness considered was the number of DS cases diagnosed. The CER was calculated as follows: CER = total cost for each threshold/number of DS cases diagnosed at each threshold. Univariate sensitivity analysis was used to test the robustness of the results by varying the cost of cfDNA.

\section{Statistical analysis}

A descriptive analysis of the data base was done for quantitative variables with standard deviation and for qualitative variables with $95 \%$ confidence interval $(95 \% \mathrm{CI})$. The cohort's advance through the decision tree was based on DS prevalence in the actual database, cfDNA (sensitivity and specificity) and screening test participation rates for karyotyping (Table 1) 
1 [16-21]. The variation in the failure rate of the cfDNA test as a function of body weight was

2 taken into consideration as was ethnicity[18,22]. Foetal loss due to invasive screening was

3 also considered for each threshold[19]. The threshold of T21T1 screening ranged from 1/51 to

$4 \quad 1 / 1000$ in steps of $1 / 50$. We used R 3.0.2. Software for this modelling.

\section{$5 \quad$ Results}

\section{Descriptive analysis of actual data}

A total of 108121 women were included in the study. The mean maternal age was 29.7 [standard deviation 4.9] years. Median measurement of NT was 1.4 [95\% CI: $0.8 ; 2.1]$. Mean gestational age at T21T1 was $12^{+6} \mathrm{WG}\left(11^{+0}-13^{+4}\right)$. In the sample, DS was diagnosed in 161 cases, giving a $0.2 \%$ [95\% CI: $0.1 ; 0.2]$ global prevalence.

At the threshold of $\geq 1 / 50$, among 76 cases of DS diagnosed, 71 were confirmed by foetal karyotyping and 5 after birth when the parents refused prenatal karyotyping (Table 2).

\section{Results of the simulation model}

For thresholds at 1/51-1/250, 43 additional cases were diagnosed (119 cases, $73.9 \%$ of total DS cases). Then, for thresholds at 1/251-1/500, 8 additional cases were diagnosed (127 cases, $78.9 \%$ of total DS cases). Finally, for thresholds at 1/501-1/1000, 2 additional cases were diagnosed (129 cases, $80.1 \%$ of total DS cases). One foetal loss was observed for a threshold of 1/251 (Table 2).

Considering that a cfDNA test costs $330 €$, the slope of the cost increase was slight from a threshold 1/51-1/250 (978 $634 €$ ), then steep up to a threshold 1/251-1/500 (1 $966576 €)$ and increased exponentially from 1/501 to 1/1000 (3 $980215 €$ ) (Figure 2). From a threshold $1 / 750$ to $1 / 1000$, no additional DS case was diagnosed, whereas the cost still increased (Figure 2). The CER was 38560 for threshold 1/51-1/500, 56471 at 1/51-1/750 and 75098 at 1/511/1000.The incremental cost per DS case diagnosed was $191637 €$ for threshold 1/51-1/500, 
$1406014 €$ at $1 / 51-1 / 750$ and $735092 €$ at 1/51-1/1000. The results were robust irrespective of

2 the cost of cfDNA (Figure 2).

3 Consequently, the most cost-effective threshold seems to be $1 / 51-1 / 500$ as $127(79.9 \%$ of total

4 DS cases) DS cases were identified for a total cost of $1966576 €$, a CER of 38560 and an 5 incremental cost per DS diagnosed of $191637 €$ for a cfDNA cost of $330 €$ (Table 3).

\section{Discussion}

In our study based on actual data, the most cost-effective threshold of cfDNA as a second-tier test was 1/51-1/500. For higher thresholds, costs increase dramatically for the diagnosis of only a few additional cases of DS.

This is the first economic study based on actual data in the general population to assess by a step by step analysis the inclusion of cfDNA in the French strategy of DS screening, following new national guidelines. The study was based on a large sample: $20.4 \%$ of women who underwent T21T1 in 2015[23]. Because of exclusion of high NT, the prevalence of DS in our sample is $0.2 \%$ whereas in France in 2012 the estimated prevalence was $0.3 \%$ [24]. However, even if the prevalence of DS in our sample is low, the percentage of DS cases identified by screening remains stable, especially at the threshold from $1 / 51-1 / 750$ to $1 / 51$ 1/1000, where no more cases of DS were identified.

First-trimester screening and cfDNA (based on the 1/1000 threshold[10]) identified up to 129 cases (corresponding to a threshold 1/51-1/750) and missed 11 cases, all of which were diagnosed by prenatal karyotyping. Considering the most cost-effective threshold of 1/51$1 / 500$, only two more DS cases were missed, but they may be identified later by secondtrimester ultrasound scan as it has been demonstrated that more than $30 \%$ of foetuses with DS can be detected among women classified as low risk after T21T1 screening[25]. Different costs for the cfDNA test were considered in a univariate sensitivity analysis. One limitation of 
our study is that non-medical indirect costs were not considered[26]. The modelling did not consider the parents' decision based on the screening results. The major ethical and legal principle governing screening and prenatal diagnosis in France is that the final decision to continue or terminate the pregnancy belongs to the parents[27,28]. Other chromosomal aberrations such as trisomy 13 or 18 and sex chromosome abnormalities can be detected by cfDNA[29], however only results for DS were considered as it is the only chromosomal anomaly implemented in the national screening programme.

In our study, only the cfDNA contingent strategy was considered since most studies have concluded that universal cfDNA is nowadays too expensive and so irrelevant $[13,30]$. We are also in accordance with current national French guidelines which recommend cfDNA as a second-tier test[10]. Few studies have tested several thresholds to identify the most costeffective cfDNA contingent strategy[11,12,14]. Chitty et al., Morris et al. and Nyet et al. demonstrated that the cfDNA contingent strategy remained cost-effective until a threshold of $\geq 1 / 150, \geq 1 / 500$ and $\geq 1 / 600$, respectively[11,12,14]. This is in line with our results regarding the dramatic cost increase at $<1 / 500$. The marginal cost of the cfDNA contingent strategy is very sensitive to the cost of cfDNA. In our study, for high-risk women (T21T1 $\geq 1 / 50)$ karyotyping was systematically proposed. To our knowledge, no study has implemented this strategy in its model.

Based on a large series of actual data, the most cost-effective threshold for cfDNA as a second-tier test in first-trimester screening seems to be 1/51-1/500. In the literature, the optimal threshold is between $\geq 1 / 150$ and $\geq 1 / 600$ according to current national guidelines of each country, assuming an unchanging budget[11,12,14,31]. For higher thresholds, costs increase dramatically for only a few additional cases of DS identified. In a recent metaanalysis of economic evaluations of prenatal screening by cfDNA testing, the authors demonstrated that despite heterogeneity between studies mainly because of several time- 
1 horizon considerations and different outcomes, the contingent strategy provides the best value

2 for money[30]. On the other hand, the universal strategy appears cost-effective when cost of cfDNA decreases. In our study, the cost of cfDNA is the one used by the French National Table of Laboratory Codes and has not been yet actualized. As already underlined, costeffectiveness studies results depend mainly of the cost of cfDNA. Another difference is also that many studies with simulated data include controversial future costs for children born with disabilities. However, a lifetime perspective is not appropriate in evaluating the prenatal screening strategy, as it appears unethical to estimate the value of life [32]. In the same way, we did not evaluate the viability of each pregnancy, as our objective was to simulate the foetal loss induced by invasive procedures. Nonetheless, the psychosocial consequences for families of these test results can be considerable and should be evaluated in economic studies[33]. Our choice to evaluate the hospital, rather than societal, point of view of the costs generated by positive test results means that we could not assess the costs of their psychosocial consequences and their effects on pregnancy outcomes[34]. Although these intangible costs are difficult to quantify, they can be approached by questionnaires, which should be used to show the full value of the DS screening strategy to health policy decision makers.

We have demonstrated in accordance with the literature that the contingent strategy is cost-effective when cfDNA testing is performed at a threshold $\geq 1 / 500$. National guidelines should take into account these results, especially in terms of opportunity costs for French society. Sensitivity analyses may be performed to assess validity of the model when cost of cfDNA will decrease as it will be used in routine screening in many countries. New thresholds may be more accurate than those used. The new challenge is to ensure that health professionals have adequate prenatal screening understanding in order to protect women's autonomy when consenting to genetic testing. 


\section{Conflict of interest}

2 The authors declare that they have no conflict of interest. 


\section{References}

1. Evans M, Johnson M, Yaron Y, Drugan A. Prenatal diagnosis : genetics, reproductive risks, testing and management. McGraw Hill Publishing Co. New York; 2006.

2. Chiu RWK, Chan KCA, Gao Y, Lau VYM, Zheng W, Leung TY, et al. Noninvasive prenatal diagnosis of fetal chromosomal aneuploidy by massively parallel genomic sequencing of DNA in maternal plasma. Proc Natl Acad Sci U S A. 2008;105:20458-63.

3. Ehrich M, Deciu C, Zwiefelhofer T, Tynan JA, Cagasan L, Tim R, et al. Noninvasive detection of fetal trisomy 21 by sequencing of DNA in maternal blood: a study in a clinical setting. Am J Obstet Gynecol. 2011;204:205.e1-11.

4. Evans MI, Krantz DA, Hallahan TW, Galen RS. Meta-analysis of first trimester Down syndrome screening studies: free beta-human chorionic gonadotropin significantly outperforms intact human chorionic gonadotropin in a multimarker protocol. Am J Obstet Gynecol. 2007;196:198-205.

5. Bianchi DW, Simpson JL, Jackson LG, Elias S, Holzgreve W, Evans MI, et al. Fetal gender and aneuploidy detection using fetal cells in maternal blood: analysis of NIFTY I data. National Institute of Child Health and Development Fetal Cell Isolation Study. Prenat Diagn. 2002;22:609-15.

6. Wapner RJ, Martin CL, Levy B, Ballif BC, Eng CM, Zachary JM, et al. Chromosomal microarray versus karyotyping for prenatal diagnosis. N Engl J Med. 2012;367:2175-84.

7. Benn P, Chapman AR, Erickson K, Defrancesco MS, Wilkins-Haug L, Egan JFX, et al. Obstetricians and gynecologists' practice and opinions of expanded carrier testing and noninvasive prenatal testing. Prenat Diagn. 2014;34:145-52.

8. Brewer J, Demers L, Musci T. Survey of US obstetrician opinions regarding NIPT use in general practice: implementation and barriers. J Matern-Fetal Neonatal Med Off J Eur Assoc Perinat Med Fed Asia Ocean Perinat Soc Int Soc Perinat Obstet. 2017;30:1793-6.

9. Chan WV, Johnson J-A, Wilson RD, Metcalfe A. Obstetrical provider knowledge and attitudes towards cell-free DNA screening: results of a cross-sectional national survey. BMC Pregnancy Childbirth. 2018;18:40.

10. Haute Autorité de santé. Place des tests ADN libre circulant dans le sang maternel dans le dépistage de la trisomie 21 foetale [Internet]. 2017 [cited 2018 Jun 12]. Available from: https://www.has-sante.fr/portail/jcms/c_2768510/fr

11. Neyt M, Hulstaert F, Gyselaers W. Introducing the non-invasive prenatal test for trisomy 21 in Belgium: a cost-consequences analysis. BMJ Open [Internet]. 2014 [cited 2015 Sep 4];4. Available from: http://www.ncbi.nlm.nih.gov/pmc/articles/PMC4225226/

12. Morris S, Karlsen S, Chung N, Hill M, Chitty LS. Model-Based Analysis of Costs and Outcomes of Non-Invasive Prenatal Testing for Down's Syndrome Using Cell Free Fetal DNA in the UK National Health Service. PLoS ONE [Internet]. 2014 [cited 2015 Sep 4];9. Available from: http://www.ncbi.nlm.nih.gov/pmc/articles/PMC3979704/ 
13. García-Pérez L, Linertová R, Álvarez-de-la-Rosa M, Bayón JC, Imaz-Iglesia I, FerrerRodríguez J, et al. Cost-effectiveness of cell-free DNA in maternal blood testing for prenatal detection of trisomy 21, 18 and 13: a systematic review. Eur J Health Econ HEPAC Health Econ Prev Care. 2017;

14. Chitty LS, Wright D, Hill M, Verhoef TI, Daley R, Lewis C, et al. Uptake, outcomes, and costs of implementing non-invasive prenatal testing for Down's syndrome into NHS maternity care: prospective cohort study in eight diverse maternity units. BMJ. 2016;354:i3426.

15. Arrêté du 23 juin 2009 fixant les règles de bonnes pratiques en matière de dépistage et de diagnostic prénatals avec utilisation des marqueurs sériques maternels de la trisomie 21 .

16. Caisse Nationale d'Assurance Maladie. Cotation des Actes Médicaux version 39.10 applicable au 01 janvier 2015. Caisse Nationale d'Assurance Maladie; 2014 p. 403.

17. Caisse Nationale d'Assurance Maladie. Table Nationale de codage de Biologie. Caisse Nationale d'Assurance Maladie; 2015 Nov.

18. Ashoor G, Syngelaki A, Poon LCY, Rezende JC, Nicolaides KH. Fetal fraction in maternal plasma cell-free DNA at 11-13 weeks' gestation: relation to maternal and fetal characteristics. Ultrasound Obstet Gynecol Off J Int Soc Ultrasound Obstet Gynecol. 2013;41:26-32.

19. Akolekar R, Beta J, Picciarelli G, Ogilvie C, D'Antonio F. Procedure-related risk of miscarriage following amniocentesis and chorionic villus sampling: a systematic review and meta-analysis. Ultrasound Obstet Gynecol Off J Int Soc Ultrasound Obstet Gynecol. 2015;45:16-26.

20. Gil MM, Quezada MS, Revello R, Akolekar R, Nicolaides KH. Analysis of cell-free DNA in maternal blood in screening for fetal aneuploidies: updated meta-analysis. Ultrasound Obstet Gynecol Off J Int Soc Ultrasound Obstet Gynecol. 2015;45:249-66.

21. Cuckle H, Benn P, Pergament E. Maternal cfDNA screening for Down syndrome--a cost sensitivity analysis. Prenat Diagn. 2013;33:636-42.

22. Tanguy J, Zeghnoun A, Dor F. Description du poids corporel en fonction du sexe et de l'âge dans la population française. Environ Risques Santé. 2007;6:179-87.

23. Agence de la biomédecine - rapport médical et scientifique [Internet]. [cited 2018 Feb 8]. Available from: https://www.agence-biomedecine.fr/annexes/bilan2016/donnees/diagprenat/01-diag_prenat/synthese.htm

24. Institut de Veille Sanitaire. Malformations congénitales et anomalies chromosomiques [Internet]. [cited 2018 May 17]. Available from: http://invs.santepubliquefrance.fr/Dossiersthematiques/Maladies-chroniques-et-traumatismes/Malformations-congenitales-et-anomalieschromosomiques/Donnees

25. Bromley B, Shipp TD, Lyons J, Groszmann Y, Navathe RS, Benacerraf BR. What is the importance of second-trimester "soft markers" for trisomy 21 after an 11- to 14-week aneuploidy screening scan? J Ultrasound Med Off J Am Inst Ultrasound Med. 2014;33:174752. 
26. Verhoef TI, Daley R, Vallejo-Torres L, Chitty LS, Morris S. Time and travel costs incurred by women attending antenatal tests: A costing study. Midwifery. 2016;40:148-52.

27. Comité Consultatif National d'Ethique. Avis sur les problèmes posés par le diagnostic prénatal et périnatal. Comité consultatif national d'Ethique; 1985 May p. 14. Report No.: 005.

28. Code de la Santé Publique. LOI n 2011-814 du 7 juillet 2011 relative à la bioéthique. 2011-814 Jul 7, 2011.

29. Benachi A, Letourneau A, Kleinfinger P, Senat M-V, Gautier E, Favre R, et al. [Performance and indications of noninvasive prenatal testing using cell free circulating fetal DNA (cffDNA) for the detection of fetal trisomy 21, 18 and 13 in France]. J Gynecol Obstet Biol Reprod (Paris). 2016;45:633-40.

30. Nshimyumukiza L, Menon S, Hina H, Rousseau F, Reinharz D. Cell-free DNA noninvasive prenatal screening for aneuploidy versus conventional screening: A systematic review of economic evaluations. Clin Genet [Internet]. [cited 2018 May 3];0. Available from: https://onlinelibrary.wiley.com/doi/abs/10.1111/cge.13155

31. Nshimyumukiza L, Beaumont J-A, Duplantie J, Langlois S, Little J, Audibert F, et al. Cell-Free DNA-Based Non-invasive Prenatal Screening for Common Aneuploidies in a Canadian Province: A Cost-Effectiveness Analysis. J Obstet Gynaecol Can JOGC J Obstet Gynecol Can JOGC. 2018;40:48-60.

32. Kostenko E, Chantraine F, Vandeweyer K, Schmid M, Lefevre A, Hertz D, et al. Clinical and Economic Impact of Adopting Noninvasive Prenatal Testing as a Primary Screening Method for Fetal Aneuploidies in the General Pregnancy Population. Fetal Diagn Ther. 2019;45:413-23.

33. John NM, Wright SJ, Gavan SP, Vass CM. The role of information provision in economic evaluations of non-invasive prenatal testing: a systematic review. Eur J Health Econ HEPAC Health Econ Prev Care. 2019;

34. Grosse SD, Wordsworth S, Payne K. Economic methods for valuing the outcomes of genetic testing: beyond cost-effectiveness analysis. Genet Med Off J Am Coll Med Genet. 2008;10:648-54. 
1 Table 1: Values estimated for the variables included in the decision model to determine

2 the most relevant threshold by performing cfDNA as the second-tier test

Value Variations Costs References

$(\%) \quad(\%)[95 \% \mathrm{CI}] \quad(€)$

\section{Participation rate}

Karyotype

$95.0 \quad[90.0 ; 100.0]$

Experts PEPRADE assumption

\section{Sensitivity \& Specificity}

Failure of cfDNA test,

$2.9 \quad[0.8 ; 4.6]$

Cuckle (2013)

all causes combined

FF $<4 \%$ (white, $60 \mathrm{~kg}$, CRL $65 \mathrm{~mm}$ )

$0.7 \quad[0.2 ; 77.4]$

Ashoor (2013)

Sensitivity of cfDNA test,

$99.2 \quad[98.5 ; 99.6]$

Gil (2015)

all studies combined

Specificity of cfDNA test,

$99.9 \quad[99.87 ; 99.95]$

Gil (2015)

all studies combined

Foetal loss after amniocentesis

$0.11 \quad[0.00 ; 0.26]$

Akolekar (2015)

Foetal loss after trophoblast biopsy

$0.22 \quad[0.00 ; 1.16]$

Akolekar (2015)

Costs and variations of costs included in the economic analysis

cfDNA test

Amniocentesis + karyotyping

Chorionic villus sampling +

karyotyping
330

491
TNCB 2018

CCAM 2018; TNCB 2018

CCAM 2018; TNCB 2018

3 cfDNA test: cell-free DNA,FF: foetal fraction, CRL: crown-rump length, CCAM:

4 Classification Commune des Actes Médicaux (French classification of medical procedures),

5 TNCB: Table Nationale de Codage de Biologie (National Table of Laboratory Codes)

6 
Table 2: Performance of a conditional Down syndrome screening strategy including cell-free DNA testing as a second-tier test for first-

\section{trimester screening}

\begin{tabular}{|c|c|c|c|c|c|c|c|c|}
\hline $\begin{array}{c}\text { Threshold } \\
\text { value }\end{array}$ & $\mathbf{n}^{\mathbf{a}}$ & cfDNA test & $\begin{array}{c}\text { TP cfDNA } \\
\text { test }\end{array}$ & $\begin{array}{c}\text { FP cfDNA } \\
\text { test }\end{array}$ & $\begin{array}{c}\text { FN cfDNA } \\
\text { test }\end{array}$ & Karyotype & $\begin{array}{c}\text { Foetal } \\
\text { loss }\end{array}$ & $\begin{array}{c}\text { Total Down syndrome } \\
\text { diagnosed }\end{array}$ \\
\hline$\geq 1 / 50$ & 420 & - & - & - & - & 76 & - & 76 \\
\hline $1 / 51-1 / 100$ & 878 & 842 & 72 & 1 & 0 & 153 & 0 & 93 \\
\hline $1 / 51-1 / 150$ & 1430 & 1365 & 84 & 2 & 0 & 198 & 0 & 104 \\
\hline $1 / 51-1 / 200$ & 1992 & 1894 & 92 & 3 & 0 & 246 & 0 & 112 \\
\hline $1 / 51-1 / 250$ & 2627 & 2494 & 98 & 3 & 0 & 290 & 1 & 119 \\
\hline $1 / 51-1 / 300$ & 3108 & 2953 & 100 & 3 & 0 & 320 & 1 & 122 \\
\hline $1 / 51-1 / 350$ & 3668 & 3482 & 101 & 3 & 0 & 359 & 1 & 122 \\
\hline $1 / 51-1 / 400$ & 4300 & 4075 & 103 & 4 & 0 & 406 & 1 & 123 \\
\hline $1 / 51-1 / 450$ & 4905 & 4649 & 107 & 5 & 0 & 446 & 1 & 126 \\
\hline $1 / 51-1 / 500$ & 5480 & 5219 & 109 & 5 & 0 & 453 & 1 & 127 \\
\hline $1 / 51-1 / 550$ & 6049 & 5741 & 110 & 7 & 0 & 511 & 1 & 127 \\
\hline $1 / 51-1 / 600$ & 6698 & 6361 & 112 & 8 & 0 & 547 & 1 & 128 \\
\hline
\end{tabular}




\begin{tabular}{|c|c|c|c|c|c|c|c|c|}
\hline $1 / 51-1 / 650$ & 7274 & 6914 & 112 & 8 & 0 & 574 & 1 & 128 \\
\hline $1 / 51-1 / 700$ & 7863 & 7474 & 113 & 9 & 0 & 605 & 1 & 128 \\
\hline $1 / 51-1 / 750$ & 8429 & 8006 & 114 & 9 & 0 & 646 & 1 & 129 \\
\hline $1 / 51-1 / 800$ & 9029 & 8574 & 114 & 9 & 0 & 682 & 1 & 129 \\
\hline $1 / 51-1 / 850$ & 9611 & 9134 & 114 & 9 & 0 & 712 & 1 & 129 \\
\hline $1 / 51-1 / 900$ & 10187 & 9682 & 114 & 9 & 0 & 744 & 1 & 129 \\
\hline $1 / 51-1 / 950$ & 10754 & 10225 & 114 & 9 & 0 & 774 & 1 & 129 \\
\hline $1 / 51-1 / 1000$ & 11299 & 10744 & 114 & 9 & 0 & 803 & 1 & 129 \\
\hline
\end{tabular}

cfDNA test: cell-free DNA test, TP: true positive, FP: false-positive, FN: false negative

${ }^{a}$ : number of women concerned based on actual data in the simulation model 
Table 3: Costs of the Down syndrome screening strategy considering different costs for cell-free DNA, CER and incremental cost.

\begin{tabular}{|c|c|c|c|c|c|c|}
\hline $\begin{array}{c}\text { Threshold } \\
\text { value }\end{array}$ & $\begin{array}{l}\text { cfDNA } \\
\text { cost } 330 \\
\text { euros } \dagger \\
\text { (euros) }\end{array}$ & $\begin{array}{c}\text { cfDNA } \\
\text { cost } 50 \text { euros } \\
\text { (euros) }\end{array}$ & $\begin{array}{c}\text { cfDNA } \\
\text { cost } 100 \text { euros } \uparrow \\
\text { (euros) }\end{array}$ & $\begin{array}{c}\text { cfDNA } \\
\text { cost } 200 \text { euros }^{\mathrm{a}} \\
\text { (euros) }\end{array}$ & $\begin{array}{c}\text { CER } \\
\text { cfDNA cost } 330 \text { euros }^{\mathrm{a}} \\
\text { (euros) }\end{array}$ & $\begin{array}{l}\text { Cost per incremental DS diagnosed } \\
\text { cfDNA cost } 330 \text { euros }^{\mathrm{a}} \\
(\text { euros })\end{array}$ \\
\hline $1 / 51-1 / 100$ & 359900 & 124140 & 166240 & 250440 & 21171 & \\
\hline $1 / 51-1 / 150$ & 555900 & 173700 & 241950 & 378450 & 19854 & \\
\hline $1 / 51-1 / 200$ & 756585 & 226265 & 320965 & 510365 & 21016 & \\
\hline $1 / 51-1 / 250$ & 978634 & 280314 & 405014 & 654414 & 22759 & \\
\hline $1 / 51-1 / 300$ & 1141171 & 314331 & 461981 & 757281 & 24808 & \\
\hline $1 / 51-1 / 350$ & 1342734 & 367774 & 541874 & 890074 & 29190 & \\
\hline $1 / 51-1 / 400$ & 1564459 & 423459 & 627209 & 1034709 & 33286 & \\
\hline $1 / 51-1 / 450$ & 1774940 & 473220 & 705670 & 1170570 & 35499 & \\
\hline $1 / 51-1 / 500$ & 1966576 & 505256 & 766206 & 1288106 & 38560 & 191637 \\
\hline $1 / 51-1 / 550$ & 2171089 & 563609 & 850659 & 1424759 & 42570 & 396149 \\
\hline $1 / 51-1 / 600$ & 2395506 & 614426 & 932476 & 1568576 & 46067 & 310283 \\
\hline
\end{tabular}




\begin{tabular}{|c|c|c|c|c|c|c|}
\hline $1 / 51-1 / 650$ & 2592166 & 656246 & 1001946 & 1693346 & 49849 & 408613 \\
\hline $1 / 51-1 / 700$ & 2793200 & 700480 & 1074180 & 1821580 & 53715 & 509130 \\
\hline $1 / 51-1 / 750$ & 2992982 & 751302 & 1151602 & 1952202 & 56471 & 406014 \\
\hline $1 / 51-1 / 800$ & 3197876 & 797156 & 1225856 & 2083256 & 60337 & 474312 \\
\hline $1 / 51-1 / 850$ & 3398009 & 840489 & 1297189 & 2210589 & 64113 & 541023 \\
\hline $1 / 51-1 / 900$ & 3595882 & 884922 & 1369022 & 2337222 & 67847 & 606981 \\
\hline $1 / 51-1 / 950$ & 3793281 & 930281 & 1441531 & 2464031 & 71571 & 672781 \\
\hline $1 / 51-1 / 1000$ & 3980215 & 971895 & 1509095 & 2583495 & 75098 & 7352 \\
\hline
\end{tabular}

cfDNA: cell-free DNA test, CER: cost-effectiveness ratio, DS: Down syndrome

${ }^{\text {a }}$ The simulation model used to calculate total cost at each threshold included the failure rate of the cfDNA test, which was performed a second time when the first failed. 


\section{Figure legends}

Figure 1: Decision tree model of Down syndrome screening using cell-free DNA (cfDNA) testing as a second-tier if first-trimester combined screening is positive, ranging from $\geq 1 / 50$ to $\geq 1 / 1000$ by step of $1 / 50$.

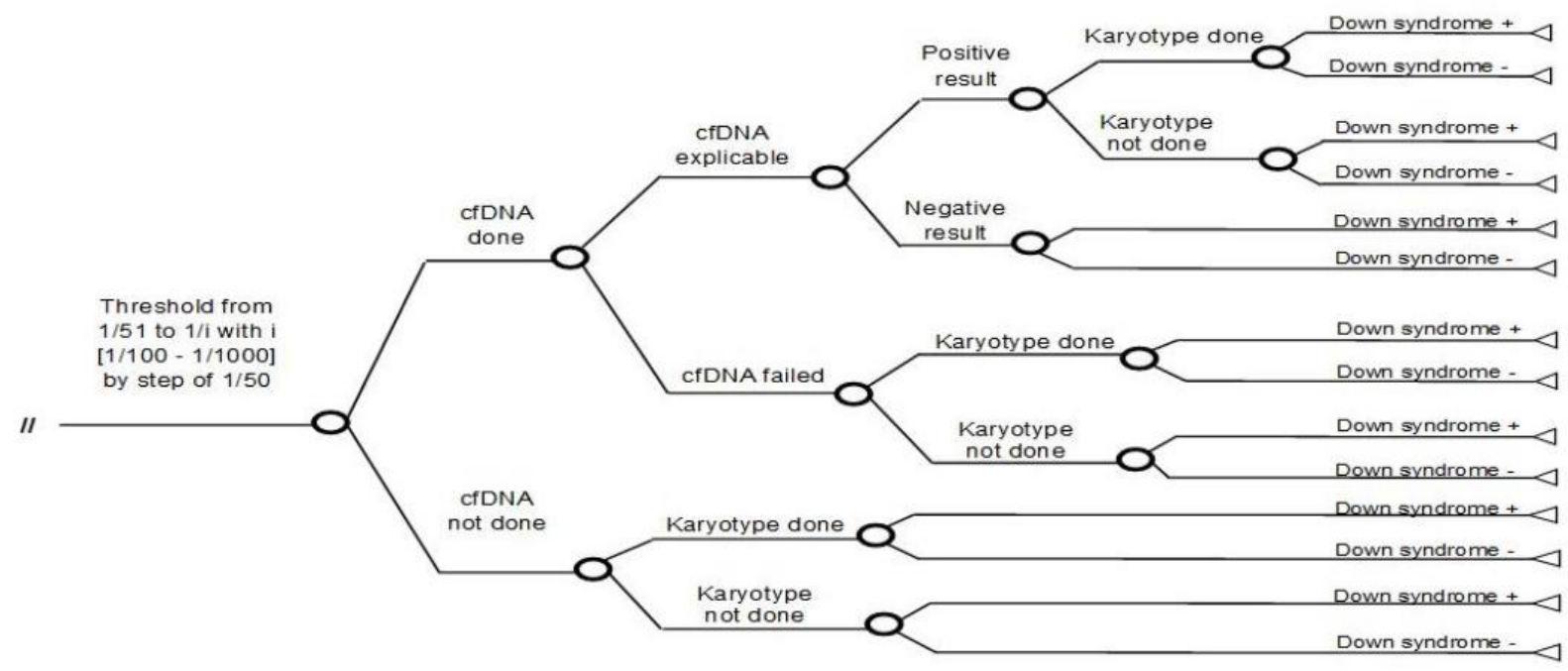


Figure 2: Cost of Down syndrome screening when performing cell-free DNA testing as a contingent strategy for a threshold of first-trimester combined screening $1 / 51-1 / 100$ to $1 / 51$ $1 / 1000$

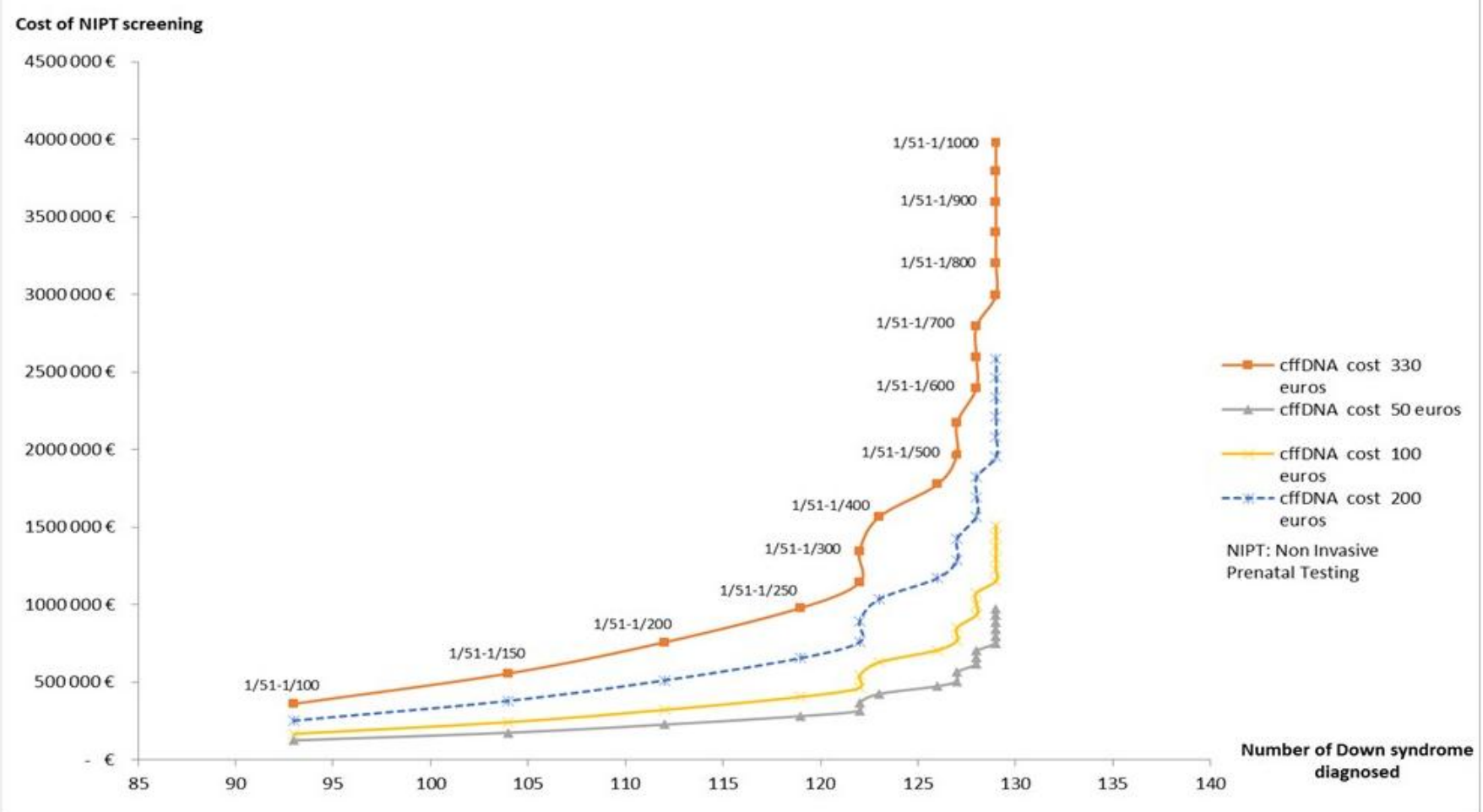

